\title{
REGISTRATION OF STOCK SPIN-OFFS UNDER THE SECURITIES ACT OF I933
}

The Securities Act of $1933^{1}$ regulates corporate distributions of securities for value to the investing public. ${ }^{2}$ The Act requires corporations to register with the Securities and Exchange Commission (SEC) those securities that are issued to the public. ${ }^{3}$ The fundamental purpose of the Act was to replace an attitude of "buyer beware" with a philosophy of full disclosure. ${ }^{4}$ President Franklin D. Roosevelt stated that the federal government has an obligation "to insist that every issue of new securities to be sold in interstate commerce shall be accompanied by full publicity and information." 5 To ensure that full publicity accompanies every issue of new securities, sections 5 (a) and (c) ${ }^{6}$ of the 1933 Act make it unlawful for any person to sell a security by means of instruments of transportation or communication in interstate com-

1. 15 U.S.C. $\$ \$ 77 a-77 a a(1976)$.

2. See Reader v. Hirsch \& Co., 197 F. Supp. 111 (S.D.N.Y. 1961). Trading among investors is governed by the Securities Exchange Act of 1934, 15 U.S.C. $\$ \$ 78 \mathrm{a}-78 \mathrm{hh}$ (1976). See Moran v. Paine, Webber, Jackson \& Curtis, 389 F.2d 242 (3d Cir. 1968). The 1933 Act can also affect the secondary trading market. For example, section 2(11) of the Act, 15 U.S.C. $\$ 77 \mathrm{~b}(4)$ (1976), defines "issuer" to include a person in a control relationship to the issuing corporation. An individual who purchases from the control person may then becoine an underwriter. This interpretation discourages trading in the secondary market by control persons. See note 36 infra.

3. 1 L. Loss, Securities Regulation 130 (2d ed. 1961).

4. SEC v. Capital Gaims Research Bureau, lnc., 375 U.S. 180 (1963). The Supreme Court stated that full disclosure is the common purpose of the Securities Act of 1933, 15 U.S.C. $\$ \S 77 \mathrm{a}-$ 77aa (1976); the Securities Exchange Act of 1934, 15 U.S.C. $\$ \$ 78 \mathrm{a}-78 \mathrm{hh}$ (1976); the Public Utility Holding Company Act of 1935, 15 U.S.C. $\$ \$ 79$ to 79z-6 (1976); the Trust Indenture Act of 1939, 15 U.S.C. $\$ \S 77$ aaa-77bbb (1976); the Investment Company Act of 1940, 15 U.S.C. $\$ \S 80(a)(1)-$ (52) (1976); and the Investment Advisers Act of 1940, 15 U.S.C. $\$ \$ 80(b)(1)-(21)$ (1976). 375 U.S. at 186. In Capital Gains Research Bureau, the Court considered a violation of the Investment Advisors Act of 1940. The full disclosure language was applied simgularly to the 1933 Act in In re Caesars Palace Sec. Litigation, 360 F. Supp. 366, 382-83 (S.D.N.Y. 1973). See also Santa Fe Indus. v. Green, 430 U.S. 462, 477-78 (1977).

5. Message from President Franklin D. Roosevelt, 77 Cong. Rec. 937 (1933). Representative Chapman reinarked that the "bill [is] imtended for the protection of the American public from the purchase of worthless and fraudulent securities." 77 CoNG. Rec. 2934 (1933) (remarks of Rep. Chapman). Representative Greenwood stated that the design of the legislation was to give every investor nnore knowledge about the assets behind securities and the practices of the issuer of the securities. 77 CoNG. ReC. 2914 (1933) (remarks of Rep. Greenwood). Representative Rayburn expressed the view that the bill's purpose was to place buyers of securities on a parity, as far as is possible, with the managements of the corporations. 77 CoNG. REC. 2918 (1933) (remarks of Rep. Rayburn).

6. I5 U.S.C. $\S \S 77 e(a)$ and (c) (1976). Section 5 is the primary operative prohibition of the 1933 Act. The statute provides in part: 
merce, or the mails, unless a registration statement ${ }^{7}$ has been filed with the SEC and has become effective. ${ }^{8}$ The term "sell" includes "every contract of sale or disposition of . . . a security or interest in a secuity, for value."

A spin-off is a corporate distribution of another corporation's securities that are owned by the distributing corporation and are distributed pro rata to the distributing corporation's shareholders. ${ }^{10}$ The distribution normally takes the form of a dividend paid by the distributing corporation. ${ }^{11}$ In the context of registration under the 1933 Act, the spin-off has often been coinpared to a stock dividend. ${ }^{12}$ A stock dividend is a pro rata distribution of a corporation's own stock to its shareholders. ${ }^{13}$ From the inception of the 1933 Act, a stock dividend

(a) Unless a registration statement is in effect as to a security, it shall be unlawful for any person, directly or indirectly-

(1) to make use of any ineans or instruments of transportation or communication in interstate commerce or of the mails to sell such security through the use or medium of any prospectus or otherwise; or

(2) to carry or cause to be carried through the mails or in interstate commerce, by any means or mstruments of transportation, any such security for the purpose of sale or for delivery after sale.

(c) It shall be unlawful for any person, directly or indirectly, to make use of any means or imstruments of transportation or communication in imterstate commerce or of the mails to offer to sell or offer to buy through the use or medium of any prospectus or otherwise any security, unless a registration statement has been filed as to such security, or while the registration statement is the subject of a refusal order or stop order or (prior to the effective date of the registration statement) any public proceeding or examimation under section $77 \mathrm{~h}$ of this title.

7. A registration statement is a form containing detailed information that the issuer must file with the SEC. See sections 6 and 7 of the 1933 Act, 15 U.S.C. $\$ \$ 77 f-77 g$ (1976); sehedule A of the 1933 Act, 15 U.S.C. $\$ 77$ aa (1976).

8. See section 8,15 U.S.C. $\$ 77 \mathrm{~h}$ (1976). The prohibition contimues until a prospectus is delivered to the intended purchaser. See section 10, 15 U.S.C. § 77j (1976).

9. 15 U.S.C. $\$ 80 \mathrm{a}-2(34)$ (1976) (emphasis added).

10. A corporate spin-off is the typical type of spin-off, and most of the pertiment legal concepts have developed in response to corporate spim-offs. As a result, much of the analysis in this Cominent centers on corporate spin-offs. This Comment, however, also discusses the issue of value in the context of partnership spin-offs, which are distributions of stock by a partnership to its partners. See text accompanying notes 189-205 infra.

11. The distributed stock can represent ownership in either a subsidiary of the distributing corporation or a separate corporation. See SEC v. Datronics Eng'rs Inc., 490 F.2d 250 (4th Cir. 1973), cert. denied, 416 U.S. 937 (1974); SEC v. Stern-Haskell, Inc., [1973 Transfer Binder] FED. SEC. L. REP. (CCH) I 94,065 (S.D.N.Y. 1973); SEC v. Harwyn Indus., 326 F. Supp. 943 (S.D.N.Y. 1971); Bromberg, Corporate Liquidation and Securities Law-Problems in the Distribution of Portfolio Securities, 3 B.C. Indus. \& CoM. L. Rev. 1 (1961); Comment, Securities Regulation: Corporate Spin-Offs as a Device for Public Distribution Without Registration, 42 U. Colo. L. REv. 111 (1970). See also text accompanying notes 112-14 infra.

12. See 1 L. Loss, Securities Regulation $517-18$ (2d ed. 1961); Lome, The Portfolio SpinOff and Securities Registration, 52 TEx. L. Rev. 918 (1974). See also text accompanying note 58 infra.

13. Peabody v. Eisner, 247 U.S. 347 (1918); Mercer v. Buchanan, 132 F. 501 (W.D. Pa. 1904); City Bank Farmers' Trust Co. v. Emst, 263 N.Y. 342, 189 N.E. 241 (1934). 
has been considered not to require registration. ${ }^{14}$ A 1936 interpretive release by the General Counsel of the SEC stated that a stock dividend would not require registration because it does not involve a "sale," since it is not for value. ${ }^{15}$

Even though a spin-off is a distribution of securities to the investing public, it is often argued by the securities bar that spin-offs do not involve a "sale," because, like recipients of stock dividends, the recipient shareholders in a spin-off give no value for the shares. If this position is valid, then spin-offs, too, are exempt from the registration provisions of the 1933 Act.16 The basis of the "no sale" argument is that a stock dividend and a spin-off do not differ when the coinparison is confined to the "for value" concept of the 1933 Act. ${ }^{17}$ The SEC has not been able to define successfully the "for value" concept for the purpose of section 5 registration of spin-offs, ${ }^{18}$ and the courts have not addressed the issue directly. ${ }^{19}$

Although the Commission has challenged spin-offs for lack of registration, ${ }^{20}$ the agency's inability to define the relationship of spin-offs to other stock distributions that do require registration under section 5 has left the law unclear. ${ }^{21}$ Corporations have thus been unable to plan spin-off transactions without obtaining individual guidance from the Cominission. ${ }^{22}$ Moreover, shareholders of a distributing corporation

14. The proposed Securities Act of 1933 originally included section 4(3), exempting "stock dividends or additional capital stock distributed among the shareholders of a corporation when such distribution is by way of dividend and not by sale." H.R. REP. No. 85, 73d Cong., Ist Sess. 16 (1933). Section 4(3), however, was eliminated from the final bill because the distribution of a stock dividend, not given for value, does not constitute a sale and is therefore exempt from registration even without section 4(3). H.R. REP. No. 152, 73d Cong, 1st Sess., 77 CoNG. REC. 3891, 3901 (1933), reprinted in 2 J. EllenBERgER \& E. MAHAR, LEGISLATIVE HisTORY OF THE SECUR1TIES ACT Of 1933 AND SECurities EXChange ACT OF 1934 at 25 (1973). The Conference Report that explained the deletion of section 4(3) spoke of stock dividends, not spin-ofis. Any claim that the "no sale" theory for spin-offs is supported by legislative history is thus unfounded. Congress certainly was aware of the distinctions relating to stock dividends discussed by the Supreme Court in Eisner v. Macomber, 252 U.S. 189 (1920), which held that Congress was not empowered by the sixteenth amendment, U.S. CoNST. amend. XVI, to tax stock dividends without apportionment.

15. Sec. Act Release No. 929 (July 29, 1936), Letter of General Counsel, 11 Fed. Reg. 10957 (1969), 1 FED. SEC. L. REP. (CCH) 11121 (discussing whether a sale of a security is involved in the payment of a stock dividend). See text accompanying notes 84-89 infra.

16. See, e.g., no-action letters to Pioneer W. Corp. (Jan. 11, 1979); Jenoa, Inc. (Nov. 3, 1978).

17. See 1 L. Loss, supra note 12, at 517-18.

18. See generally Lorne, supra note 12. See text accompanying notes 77-138 infra.

19. See text accompanying notes 25-76 infra.

20. See notes $77-138$ infra and accompanying text.

21. Defining this relationship is especially important as the SEC reassesses its disclosure requirements. See proposed rule 13e-3, 42 Fed. Reg. 60100 (1977), which, in amended form, is now rule $13 \mathrm{e}-3,17$ C.F.R. $\$ 240.13 \mathrm{e}-3$ (1980).

22. The SEC has issued a substantial number of no-action letters answering requests for guidance on the most basic types of spin-offs. See text accompanying notes 110-38 infra. 
receive stock in another corporation without the same disclosure of imformation required of stock traded in the market. The critical inquiry, however, is clear: does the "no sale" theory applied to stock dividends also apply to spin-offs?

This Comment will approach the issue of registration of corporate spin-offs by analyzing the nature of the value flowing from the recipient shareholder. Although the value flowing to the distributing corporation can be easily measured ${ }^{23}$ and used as the basis of a section 5 violation, the inajor enforcement provisions of the 1933 Act are actually designed to protect the shareholders receiving stock in the distributed corporation. ${ }^{24}$ Therefore, the problem of a spin-off transaction is to identify the value flowing from the shareholder. The Comment will begin by discussing the methods the courts have used in approaching the issue. It will examine the SEC's attempts to regulate spin-offs and will suggest an analysis by which value can be found in a spin-off transaction. The Comment will also consider the issue in the context of a partnership spin-off. Adoption of the proposed analysis would facilitate the development of a uniform policy of registration to protect investors and allow corporations to plan successful spin-offs.

\section{Corporate Spin-OFFs}

\section{A. The Courts' Approaches.}

The federal courts have seldom been asked to interpret the registration requirements of section 5 of the 1933 Act in the context of spin-

23. See text accompanying notes 58-61 infra. Value also flows to corporations in transactions that admittedly do not require registration. For example, a stock split may benefit the corporation by increasing stock distribution. This increased distribution may make the stock price more stable. Cf. SEC v. Harwyn Indus., 326 F. Supp. 943 (S.D.N.Y. 1971) (value flowed to the corporation in the form of an increased ability to market shares and thereby finance operations). See text accompanying note 61 infra.

24. Six provisions in the 1933 Act protect against violations of the Act (that is, they protect the purchaser against loss). Sections 20 and 24,15 U.S.C. $\$ \$ 77 t, 77 \times(1976)$, apply to all violations of the 1933 Act. Section 17(a), 15 U.S.C. $\$ 77 q(a)$ (1976), forbids fraud "in the offer or sale of any securities." The same problems exist in defining value in a sale, but fraud requires damages or potential for damages, ie., value flowing from the shareholders in the context of spin-offs. Section 17(b), 15 U.S.C. $\& 77 q(b)$ (1976), involves value to the corporation, but merely forbids publication of advertisements describing securities without disclosure of that value. The other two sections that specifically provide the recovery to be received from registration violations address only the value flowing from the shareholders: Section 12, 15 U.S.C. $\$ 77 /$ (1976), states that a person who sells an unregistered security shall be hable for the "consideration paid for such security," or damages if the purchaser no longer owns the security. The measure of damages is the value lost by the purchaser (value given up minus value received on a disposition). Section 11 (e) assesses the same ineasure of damages for a false statement in a registration statement under that section. 15 U.S.C. $\$ 77 \mathrm{k}$ (e) (1976). All these provisions are generally directed at protecting the value flowing from the shareholder. 
off transactions. ${ }^{25}$ When the issue has arisen, moreover, the Securities and Exchange Commission has not attempted to define a spin-off as a sale but instead has sought to prevent perversion of the registration process. For example, in SEC v. Datronics Engineers, Inc. ${ }^{26}$ a contract bound a corporation to distribute stock of another corporation about which there was no public information. The court found that the distribution of the unregistered stock was a flagrant attempt to swindle the investing public: "The market and the public character of the spun-off stock were fired and fanned by the issuance of shareholder letters announcing future spin-offs, and by information statements sent out to the shareholders." 27 In addition, the district court in SEC v. Stern-Haskell, Inc. ${ }^{28}$ stated that the "defendants engaged in a scheme to sell securities to the public by evading the registration requirements of law and . . . acted in bad faith and with a clear purpose of imposing upon an uninformed and unsuspecting public in utter disregard of the securities laws."29 The opinion in Stern-Haskell, however, never identified any value in the spin-off transaction. ${ }^{30}$ No court has addressed the issue of whether a shareholder gives value in a typical spin-off transaction. ${ }^{31}$

In the few cases concerning spin-offs that the courts have decided, they have used three approaches. Initially courts ignored the spin-off, finding other violations of the securities laws. ${ }^{32}$ Another method, employed by the Court of Appeals for the Fourth Circuit, is to find value in a spin-off in the developinent of a trading market in the spun shares. ${ }^{33}$ The third and most popular approach, however, has been to collapse the transaction and find value flowing from the market purchasers, througli the recipient shareholders, and to the corporation. ${ }^{34}$

25. Only four cases have interpreted section 5 in spin-off transactions. See SEC v. Datronics Eng'rs, Inc., 490 F.2d 250 (4th Cir. 1973), cert. denied, 416 U.S. 937 (1974); SEC v. Stern-Haskell, Inc., [1973 Transfer Binder] FED. SEc. L. REP. (CCH) If 94,065 (S.D.N.Y. 1973); SEC v. Harwyn Indus., 326 F. Supp. 943 (S.D.N.Y. 1971); SEC v. LesStuds Corp. [1970-1971 Transfer Binder] FED. SEC. L. REP. (CCH) I 92,866 (S.D.N.Y. 1970). The SEC brought all four actions. A case involving criminal convictions arose out of the Stern-Haskell spin-off. United States v. Rubinson, 543 F.2d 951 (2d Cir.), cert. denied, 429 U.S. 850 (1976).

26. 490 F.2d 250 (4th Cir. 1973), cert. denied, 416 U.S. 937 (1974).

27. 490 F.2d at 254.

28. [1973 Transfer Binder] FED. SEC. L. REP. (CCH) \ 94,065 (S.D.N.Y. 1973).

29. Id. at 94,292 .

30. See note 37 infra.

31. Each transaction that the SEC has attacked involved numerous violations of the securities laws. It was therefore unnecessary for any court to search for value in the spin-off to justify its holding.

32. See text accompanying notes $35-41$ infra.

33. See text acconipanying notes $42-50$ infra.

34. See text accoinpanying notes 51-76 infra. 
Each of these three theories serves the laudable purpose of condemning readily apparent violations of federal securities law registration requirements; but none satisfactorily meets the burden of finding a "sale" in a spin-off by isolating the value flowing from the recipient shareholders.

The first judicial approach finds a sale and a section 5 violation without any discussion of the "for value" requirement of section 2(3).35 Implicit in this approach is the notion that the distributing corporation was acting as an underwriter by participating in an integral step of the planned distribution to the public. ${ }^{36}$ In short, the corporation distributing the stock was in control of or serving as an agent for the corporation that originally issued the stock. Under this first approach, a court inay confidently enjoin a spin-off without discussing the giving of value when the evidence reveals a multitude of obvious and extreme violations of the securities laws. A wrong conclusion on the question whether there was a sale in the spin-off would generally not be sufficient to change the trial court's decision to issue the injunction. ${ }^{37}$ If a

35. See, e.g., SEC v. LesStuds Corp., [1970-1971 Transfer Binder] FED. SEc. L. REP. (CCH) If 92,866 (S.D.N.Y. 1970). In LesStuds, one month prior to completion of the spin-off the SEC challenged the transaction. LesStuds was incorporated with assets of $\$ 8,500$ cash and a valueless consulting contract. LesStuds then merged with a seven-day-old subsidiary of Atomic Fuel Extraction Corp., the publicly-held corporation that made the distribution. After the dividend distribution of LesStuds stock by Atomic Fuel, the stock certificates were sent by LesStuds directly to the Atounic Fuel shareholders, bypassing the merger. This bypass demonstrated the lack of substance in the merger. The SEC was able more easily to prove fraud and manipulation in the subsequent trading of LesStuds stock, however, than im the failure to register the distribution. The court apparently considered it outrageous for the stock of a corporation with a net worth of less than $\$ 10,000$ to be quoted and traded at over $\$ 3$ per share, or a market value of $\$ 1,875,000$. The earning power of LesStuds, the true indicator of its value, was not addressed. As a result of the market manipulation, the court permanently enjoined future violations of the securities laws by the parties involved.

36. See SEC v. Culpepper, 270 F.2d 241 (2d Cir. 1959). An underwriter is any person who offers or sells for an issuer in connection with the distribution of securities, or any person who participates directly or indirectly in such a distribution. See Pharo v. Smith, 621 F.2d 656, 671 (5th Cir. 1980). The term "issuer" includes a person in a control relationship to the issuing corporation. 15 U.S.C. \& 77(b)(11) (1976) provides in part:

The term "underwriter" means any person who has purchased from an issuer with a view to, or offers or sells for an issuer in connection with, the distribution of any security, or participates or has a direct or imdirect participation in any such undertaking, or participates or has a participation in the direct or mdirect underwriting of any such undertaking .... As used in this paragraph the term "issuer" shall mclude, in addition to an issuer, any person directly or indirectly controlling or controlled by the issuer, or any person under direct or indirect conmon control with the issuer.

37. In SEC v. Stern-Haskell, Inc., [1973 Transfer Bimder] Fed. SEC. L. REP. (CCH) q 94,065 (S.D.N.Y. 1973), the court never addressed the question of value in spin-offs. National Ventures, Inc., purchased, for nommal consideration, 200,000 shares of three different privately-owned corporations. The purchase contract expressly required National Ventures to distribute the purchased shares to its shareholders. The distributing corporation retamed no shares, but control groups of National Ventures received a substantial majority of the 200,000 shares. Moreover, a 
judge is not forced to address a question which has no definitive answer, it is natural that he will avoid doing so. In many cases, however, the spin-off is the cornerstone of the transaction that is being attacked. A court should address the basis of an illegal transaction instead of skirting the issue. An injunction prohibiting the distributing corporation from acting as an underwriter ${ }^{38}$ or from manipulating the market ${ }^{39}$ will not necessarily prevent the spin-off. ${ }^{40}$ Furthermore, judicial guidelines concerning spin-offs need to be developed ${ }^{41}$ to make it possible for corporations to plan necessary spin-off transactions.

A second method of finding a violation of section 5 is to find that, as a result of a spin-off, value-or, more specifically, an increment of value-accrues to the distributing corporation from the development of a trading market in the shares that it spun off. ${ }^{42}$ Value, in the form of the increased price of the shares traded, can be said to flow to the distributing corporation if that corporation retams some of the stock, or to the controlling shareholders, if shares are distributed to them. In $S E C$ v. Datronics Engineers, Inc. ${ }^{43}$ the Court of Appeals for the Fourth Circuit implied that four criteria must be met for there to be value under this hypothesis: (1) the distributing corporation must have a prior legal obligation to distribute the shares; 44 (2) the distributing corporation unust retain some of the shares; (3) the creation of a trading market must be "spurious"; 45 and (4) the distributing corporation inust expect that the only benefit it will receive is the creation of the public market

significant manipulation of the subsequently developed trading market followed the distribution. At trial the fraud and market manipulation made it easy for the court to find securities laws violations and to enjoin further non-observance. That broad injunction included spin-off transactions.

38. See SEC v. Datronics Eng'rs, Inc., 490 F.2d 250, 254-55 (4th Cir. 1973), cert. denied, 416 U.S. 937 (1974); cf. SEC v. Harwyn Indus., 326 F. Supp. 943, 955-56 (S.D.N.Y. 1971) (no injunction issued although the court found the distributing corporation to be an underwriter).

39. See SEC v. Datronics Eng'rs, Inc., 490 F.2d at 254-55.

40. A corporation may own stock in another corporation that it does not control, which stock it did not obtain with a view toward distributing it. A spin-off of the stock without market manipulation is also possible. The lack of underwriter status and market manipulation, however, does not change the character of the spin-off. See text accompanying notes 126-38 infra.

41. For many years attorneys planned spin-offs with the belief that no value and thus no sale was involved. See SEC v. Harwyn Indus., 326 F. Supp. 943, 955-57 (S.D.N.Y. 1971). More recent no-action requests indicate that businessmen are still seeking legal advice relating to spin-offs, and that the transactions are still being consummated.

42. See, e.g., SEC v. Datronics Eng'rs, Inc., 490 F.2d at 254. In a 13-month period in 1968 and 1969, Datronics spun off nine corporations to one thousand shareholders. The stock appreciated in value substantially after the distribution, only to collapse later. Id.

43. 490 F.2d 250 (4th Cir. 1973), cert. denied, 416 U.S. 937 (1974).

44. This requirement was an atteinpt to distinguish a spin-off from a dividend of portfoho investinents.

45. The court coined the term "spurious"; Judge Widener, in his concurrence, defined spurious to inean illegitimate. 490 F.2d at 255. See BlaCK's Law Dictionary 1258 (5th ed. 1979). 
for the stock. A corollary to this last criterion is the valid business purpose test. If an independent valid business purpose exists for the spinoff, the distributing corporation receives a benefit other than the creation of the public market. This obviates the notion that the corporation spun off the shares for the sole purpose of creating a spurious inarket. ${ }^{46}$

In Datronics the court found that the transaction satisfied the receipt-of-value criteria, and thereby violated section 5 of the 1933 Act. ${ }^{47}$ The spin-off began with a merger of the original issuer into a subsidiary of Datronics. The primcipal owners of the original issuer received a inajority interest. Agreements with the original issuers bound Datronics to distribute among its shareholders the subsidiary stock that it did not retain. Reserving approximately one-third of the shares for itself, Datronics paid a dividend of the remaining stock. Datronics received no direct payinent for the spim-off. The mere distribution of stock to one thousand shareholders, however, resulted in the creation of a trading inarket for the stock. In fact, the price of the stock rose im the trading market and "the stock retaimed by Datronics was thereby given an added increment of value." 48

The "mcrement of value" theory is of limited usefulness. It applies only when the distributing corporation retains stock. ${ }^{49}$ For a court to find value by this theory, the distributing corporation inust be paid for its participation with stock in the spun-off corporation. The approach fails to recognize that the registration requirements should apply also to spin-offs in which the distributing corporation retains no stock in the distributed corporation..$^{50}$ The issue of whether the distributing corporation retains stock is unrelated to the need of investors to

Webster's defines spurious as false or not genuine. WeBSTER's NEW WORLD Dictionary 1380 (1976).

46. $490 \mathrm{~F} .2 \mathrm{~d}$ at $255-56$ (Widener, J., concurring). The independent valid business purpose has become a favorite justification of corporations seeking SEC approval for spin-offs. See, e.g., no-action requests of Cook Inlet Region, Inc. (Jan. 12, 1979); Pioneer W. Corp. (Jan. 11, 1979); Western Digital Corp. (Dec. 1, 1978); American Television and Communications Corp. (July 27, 1978); Trans Graphics, Inc. (Apr. 12, 1976). See generally Brockmeyer, "Going Public" Through a “Spin-Off' or Public Shell, 52 Calif. ST. B.J. 208 (1977); Orlanski, Going Public Through the Backdoor and the Shell Game, 58 VA. L. REv. 1451 (1972).

47. 490 F.2d at 254.

48. Id.

49. The Court of Appeals for the Second Circuit thought value existed in the retention of shares in the distributed corporation by insiders in control of the distributing corporation. International Controls Corp. v. Vesco, 490 F.2d 1334 (2d Cir.), cert. denied, 417 U.S. 932 (1974). Even if value can be attributed to the retention of shares by the distributing corporation, the corporate entity cannot be so easily disregarded by giving the corporation value for a benefit received by a control shareholder. See Lorne, supra note 12, at 926.

50. See text accompanying notes 149-55 infra. 
obtain information about the distributed company, which is the major purpose of registration under the 1933 Act.

The third and most widely approved ${ }^{51}$ approach to the question of value in spin-offs was used in $S E C$ v. Harwyn Industries. ${ }^{52}$ Harwyn Industries was a small publicly-held corporation with approximately six hundred shareholders. ${ }^{53}$ Harwyn also owned several inactive subsidiaries that it was willing to use for spm-off transactions. The spm-off plans consisted of the following transactions: (1) the acquisition by the Harwyn subsidiaries of other corporations' assets in exchange for issuance of controlling interests in the subsidiaries to those contributing such assets; (2) the spim-off distribution by Harwyn to its stockholders of the unregistered shares of its subsidiary; and (3) the development of an over-the-counter tradimg market in the unregistered shares thus spun off.54 The spm-offs, however, did not appear to be conscious schemes to circumvent the section 5 registration requirements. ${ }^{55}$ The SEC responded to the first three Harwyn transactions by issuing Release No. 4982,56 which was made public shortly before the fourth spinoff. 57 When the release proved ineffective, the Commission sought imjunctive relief in federal district court.

The defendants in Harwyn argued that the spm-offs were not "for value" received froin the shareholders, but were merely distributions of what was already owned by the shareholders, as in the case of a stock dividend. ${ }^{58}$ The court nevertheless found value by collapsing into one

51. See Long, Control of the Spin-Off Device Under the Securities Act of 1933, 25 OKLA. L. Rev. 317 (1972); Schief \& Sippel, The Corporate "Spin-Off” Device: Securities Act and Exchange Act Considerations, 16 How. L.J. 719 (1971); Note, Securities Regulation-The Corporate Spin Off and Registration Under the Securities Act of 1933, 50 N.C.L. REv. 179 (1971); 25 VAND. L. REV. 454 (1972).

52. 326 F. Supp. 943 (S.D.N.Y. 1971).

53. Id. at 946 .

54. Id. at $945-46$.

55. Several parties to the spin-offs were concerned only with the registration requirements of the transaction and sought legal assistance. Id. at 948-49. At least two of the issuers of unregistered securities filed a form 10 registration statement pursuant to section 12 of the 1934 Act, 15 U.S.C. $\$ 78 /(1976)$. 326 F. Supp. at 951. Counsel for Harwyn also inquired at the SEC about the need for registration for these spin-off transactions; the SEC gave no answer. Id. at 946. These spin-offs were not schemes designed solely to circumvent a known need for registration, and the court recognized this by denying the injunctive relief sought by the SEC. The lack of evil intent, however, is no solace to those who bought shares in one of the companies at $\$ 22$ and watched the price drop to $\$ 1$ per sliare.

56. Sec. Act. Release No. 4982 (July 2, 1969), 17 C.F.R. § 231.4982 (1980).

57. 326 F. Supp. at 950 .

58. The argument is based upon Sec. Act. Release No. 929, supra note 15. From the language of the Harwyn opinion, the argument's credibihty seems due more to the SEC's inability to refute it than to the defendant's abihity to press it or the court's willingness to accept it. Cf. Bromberg, supra note 11, at 3-7 (arguing for no value). 
transaction the asset sale agreement, the spin-off, and the distribution. ${ }^{59}$ The actual value was supposedly received in two ways: "in the form of contribution of substantially new assets to each subsidiary and [im] the creation of a public market in the shares with its resulting benefits to the defendants, including insiders." 60 Each subsidiary received new assets when Harwyn exchanged shares of the subsidiary for assets of the private corporation wanting to go public. The value received by the subsidiary from the creation of the public market was the increased ability to market and hypothecate shares to finance its operations. ${ }^{61}$ The Harwyn insiders received the opportunity to sell at a profit the sliares distributed to them.

The district court supported its decision with several reasons representative of the general purposes of the Securities Act of 1933.62 First, the effect of the spin-off was to convert a Harwyn subsidiary into a publicly-lield company. ${ }^{63}$ In addition, Harwyn did not file a registration statennent, althougli the necessary information was available to it. ${ }^{64}$ Witlout the benefit of a registration statement, those who purchased sliares from the Harwyn shareholders lacked adequate information. "Thus, regardless of the precise language of the federal securities laws, it is readily apparent that the Harwyn spim-offs violated the spirit and purpose of the registration requirenients of $\S 5$ of the '33 Act . . . "65 Like the Court of Appeals for the Fourth Circuit in Datronics, the district court in Harwyn implied that a spin-off with a valid busmess purpose may be permissible under section 5. The Harwyn court determined that the lack of a business purpose for the spin-off indicated that the sole notive was to create a trading market in stock without 1933 Act disclosure. 66

59. The SEC advocated the collapsed-transaction approach in 1969. Sec. Act Release No. 4982 (July 2, 1969), 34 Fed. Reg. 11581 (1969), 1 FED. SEC. L. REP. (CCH) I 3055. Release No. 4982 was also available to the courts in SEC v. LesStuds Corp., [1970-1971 Transfer Binder] FED. SEC. L. REP. (CCH) I 92,866 (S.D.N.Y. 1970), and SEC v. Stern-Haskell, Inc., [1973 Transfer Binder] FED. SEC. L. REP. (CCH) I 94,065 (S.D.N.Y. 1973); however, neither court used the release.

60. $326 \mathrm{~F}$. Supp. at 951 .

61. Id. at $952-53$.

62. The most important purpose recognized by Judge Mansfield was "not only to protect immediate recipients of distributed securities . . . but also [to protect] subsequent purchasers from them." Id. at 953 . This statement does not diminish the need to protect the innnediate recipients.

63. Id. at 949.

64. Id.

65. Id. at 953 .

66. Id. at $952 \mathrm{n} .1$. The valid-business-purpose test is also consistent with Release No. 4982. "This release does not attempt to deal with any problems attributable to more conventional spin offs . . ." Sec. Act Release No. 4982, supra note 59, at 11,581. See note 89 infra and accompanying text. 
Both the Datronics and Harwyn methods of finding value require that there be a contracted-for distribution and the subsequent creation of a spurious trading market for the stock spun off. But while the obligation to distribute stock may transform a company into an underwriter, it does not necessarily indicate that the distributing company must have received value. ${ }^{67}$ Although the fraudulent and illegal trading market may provide a sound basis upon which a court can condemn the transaction, it does not adequately limit spin-offs. ${ }^{68}$ Moreover, the shareholders who directly receive the spun-off stock need at least as much protection as those who purchase in the open inarket.69

The Harwyn court also found that the defendants received value in the contribution of new assets to the subsidiary. ${ }^{70}$ This criterion, however, is also insufficient to define the illegal spin-off. The "assets added" concept of value does not solve the problem of a spin-off of shares in a wholly-owned subsidiary whose assets were contributed only by the parent corporation. In that situation a spin-off is possible even though no value is given to the parent. Both the Harwyn-type spin-off and the wholly-owned subsidiary spin-off, however, must be treated the same. The Securities Act of 1933 is directed at disclosure. In both types of spin-offs, mvestors receive distributions of stock about which the public and the recipient shareholders have inadequate knowledge. The disclosure requirements should not depend upon whether the assets were purchased or received free froin the parent corporation. The imfusion of assets is, in fact, irrelevant to value in a spin-off. ${ }^{71}$

The valid-business-purpose test ${ }^{72}$ to which the courts in Datronics and Harwyn alluded has been taken by many to be a true test of legality. ${ }^{73}$ As the lack of a busmess purpose makes a transaction more suspect, the need to search for value becomes more urgent; ${ }^{74}$ however, the

67. See SEC v. Datronics Eng'rs, Inc., 490 F.2d at 254; SEC v. Harwyn Indus., 326 F. Supp. at 955 .

68. Suppose the persons in control of the spin-off did not create a market for the stock. Presumably, the innocent minority shareholders would be able to sell their stock with innnunity as a section 4(1) exempt transaction. The trading of stock on public markets without adequate information would still defeat the purpose of the 1933 Act. See text accompanying notes 1-5 supra.

69. Investors who purchase stock in the market make individual decisions to buy. A shareholder of a distributing corporation receives the spun-off shares in the mail.

70. See text accompanying note 60 supra.

71. For example, if a gift of assets occurred several years prior to the spin-off (a very patient distribution), it could not be claimed that the contribution of assets added value to the spin-off. See Lorne, supra note 12, at 927.

72. See text accompanying notes $46 \& 66$ supra.

73. See note 46 supra and accompanying text.

74. The lack of a valid business purpose nnay nove a court to infer that the corporation received value from the spin-off. Why else would the corporation enter into such a transaction? 
valid-business-purpose test does not assist in ascertaining what that value is. Indeed, the purpose of the 1933 Act-the protection of the public through disclosure of investment information-is unaffected by the presence or absence of a valid busmess purpose. The only possible function of the valid-business-purpose test is to determme whether a particular type of spin-off, though technically violative of the 1933 Act registration provisions, should nevertheless be allowed for reasons of public policy. Sucl a determination should be left to the Securities and Exchange Commission. ${ }^{75}$ Similarly, the fact that the recipient sharelolders had access to adequate information does not indicate whether they gave value for the stock. ${ }^{76}$ No one would refuse a gift of stock, even without information on the issuer. Like the valid-business-purpose test, the usefulness of this investigation for adequate consideration is that it helps determine which, if any, spin-offs are tolerable even though they technically violate registration requirements.

In short, the courts have made decisions concerning obvious securities laws violations based upon the mdividual facts of each case, instead of by addressing the issue of value for all spin-offs. While this approach inay liave been acceptable in the cases discussed above, the decisions provide hittle guidance for future spm-off transactions.

\section{B. The SEC Leadership.}

The Securities and Exchange Commission has broad authority to proinulgate rules and regulations necessary to carry out the registration requireinents of the 1933 Act. ${ }^{77}$ The Commission has used its ruleinaking authority to attack spm-off transactions at every point in their developinent. For example, Release No. $4982^{78}$ prohibits the abusive spin-off; ${ }^{79}$ rule $15 \mathrm{c} 2-11^{80}$ controls market manipulation; ${ }^{81}$ and rule $145^{82}$ curtails the practice of forming subsidiaries merely to be spun off. ${ }^{83}$ The SEC has also attempted to discourage registration violations

75. See note 77 and text accompanying notes $139-48$ infra.

76. If a corporation does not have the imformation necessary to file a registration statement, the inability to file the statement is a risk the corporation that acquired the unregistered securities must bear. The corporation and its management are in a better position to accept the risk than are its shareholders or the public.

77. 15 U.S.C. $\$ 775$ (1976); cf. Lowenfels, The Case Against the Proposed Federal Sccurities Code, 65 VA. L. REv. 615 (1979) (criticizing the American Law Institute's proposed code for giving the SEC too much authority).

78. Sec. Act Release No. 4982, supra note 59.

79. See notes 87-89 infra and accompanying text.

80. 17 C.F.R. $\$ 240.15 c 2-11$ (1980).

81. See notes 90-97 infra and accompanymg text.

82. 17 C.F.R. $\$ 230.145$ (1980).

83. See notes 98-109 infra and accompanying text. 
by seeking injunctions and by responding negatively to no-action letters from those seeking to use spin-offs; negative responses indicate that the SEC would be willing to attack the planned transactions in court.

1. Release No. 4982. Just three years after the enactment of the Securities Act of 1933, the SEC proclaimed in Release No. 929 that a stock dividend is not a sale and does not require registration. ${ }^{84}$ In that release the General Counsel for the Commission was addressing the distribution of an issuer's stock to the issuer's stockholders. ${ }^{85}$ Unfortunately, the General Counsel did not have detailed information about the transaction and answered the registration issue in general terms. Many attorneys subsequently interpreted the release to apply to spinoffs as well as stock dividends. ${ }^{86}$

The SEC attempted to correct misunderstandings about spin-offs in 1969 with Release No. 4982.87 This release addressed the shell game exemplified by the facts in $S E C$ v. Harwyn Industries. ${ }^{88}$ Agam, however, the Commission left rooin for securities lawyers to manipulate transactions in order to avoid registration. Release No. 4982 prohibited only the type of spin-off that was attacked in Harwyn, implying that other types of spin-offs might validly elude registration. The implication was strengthened by the stateinent that "[t]]his release does not atteinpt to deal with any probleins attributable to more conventional spin offs, which do not involve a process of purchase of securities by a publicly owned company followed [immediately] by their spin off and redistribution in the trading inarkets." 89

2. Rules. In 1969 the Securities and Exchange Commission also attacked spin-offs with rule $15 \mathrm{c} 2-11 .{ }^{90}$ This rule makes it fraudulent, inanipulative, and deceptive for a broker or dealer to publish a quotation for a security unless one of the following has occurred: (1) the issuer has coinplied with the provisions of section 5 and the broker or

84. Sec. Act Release No. 929, supra note 15.

85. Id.

86. See SEC v. Harwyn Indus., 326 F. Supp. 943, 954 (S.D.N.Y. 1971).

87. Sec. Act Release No. 4982 (July 2, 1969), 17 C.F.R. § 231.4982 (1980), 1 FED. SEC. L. REP. (CCH) If 3055 (1969).

88. 326 F. Supp. 943 (S.D.N.Y. 1971). See text accompanying notes 52-66 supra.

89. Sec. Act Release No. 4982, supra note 59.

90. 17 C.F.R. $\$ 240.15 \mathrm{c} 2-11$ (1980). The SEC, unable effectively to combat unregistered spin-offs with the Securities Act of 1933, found a more formidable weapon in section 15 of the Securities and Exchange Act of 1934, 15 U.S.C. \& 78(o) (1976). The requirements for satisfying the rule, however, are designed to ensure at least partial compliance with the Securities Act of 1933. See generally Comment, The Effects of SEC Rule 15c2-11 on the Sale of Spin Off Securities, 19 U.C.L.A. L. REv. 487 (1972). 
dealer keeps a section $10^{91}$ prospectus in his files; (2) the issuer has registered the securities in accordance with regulation $A ;{ }^{92}$ (3) the issuer is a reporting company under the $1934 \mathrm{Act} ;{ }^{93}$ or (4) the broker or dealer has on file, and available upon request, certain specified information. The information that inust be kept on file is less extensive and less expensive to obtain than information required by section 5 registration. ${ }^{94}$

Rule $15 \mathrm{c} 2-11$ is designed to prevent spin-offs that are outrageous attempts to circumvent section 5 registration. ${ }^{95}$ The rule, however, fails in two respects to protect investors adequately. First, it does not give any protection to the innocent minority shareholder who receives stock im a spim-off. For example, if a corporation is induced to spin off a subsidiary for a valid and substantial business reason, the shareholder may receive stock of a corporation about which he has bittle or no information. Nevertheless, rule $15 \mathrm{c} 2-11$ prevents him froin selling the stock through a broker or dealer. ${ }^{96}$ The rule also begs the real question of whether a spin-off is subject to the registration provisions of the 1933 Act. This sidestep by the SEC in fact perverts the purpose of the 1933 Act. If the 1933 Act does not currently require disclosure, it is up to the legislature, not the Commission, to alter the law. On the other hand, the 1933 Act was certainly designed to provide initial investors with information about the issuing corporation, and the Act should not be circumvented merely by compliance with rule $15 \mathrm{c} 2-11$. Despite these shortcounings, rule $15 \mathrm{c} 2-11$ effectively provides some protection for the market by preventing holders of a spun stock froin trading it in the market without ininimal information. ${ }^{97}$

91. 15 U.S.C. $\$ 77 \mathrm{j}(1976)$; see note 7 supra.

92. 17 C.F.R. $\$ 230.251-.264$ (1980). Regulation $A$ sets forth the information required in a registration statement.

93. The reporting provisions are sections 13 and $15(\mathrm{~d}), 15$ U.S.C. $\$ \S 78 \mathrm{~m}, 780$ (d) (1976). Also exempt from rule $15 \mathrm{c} 2-11$ are companies excinpt from section 12 , 15 U.S.C. $\S 78 /(1976$ ), and under subsections (2)(B) and (2)(G).

94. See Comment, supra note 90 , at 504. The required information is adequate to protect purchasers in the trading market, if it is requested. Rule $15 \mathrm{c} 2-11$ mandates disclosure of all the information a typical public mvestor will need.

95. Rule 15c2-11 will effectively eliminate the creation of a spurious market in the shares spun off. It will also curtail the need for the SEC to seek relief in the courts. On the other hand, those willing to violate the registration requirements nay be just as willing to violate rule $15 \mathrm{c} 2-11$. See generally Comment, supra note 90.

96. Presumably, a good faith spin-off will not produce such a rcsult. The distributing corporation will provide some information to the shareholders before the spin-off. In gencral, the corporation that was spun off will also supply at least one broker or dealer with the necessary information. Unfortunately, managenent and control shareholders, who may not want to sell, are not always so anenable to providing facts about their companies.

97. Rule 15c2-11 was promulgated after the spin-offs that the SEC attacked in the courts. See text accoinpanying notes 51-56 supra. 
Another weapon in the SEC's war against spin-offs is rule $145 . .^{98}$ Prior to the promulgation of rule 145, rule $133^{99}$ exempted mergers and transfers of assets from the registration requirements of section 5.100 These exemptions became the initial phase in the abusive spin-off schemes that the SEC sought to prevent. ${ }^{101}$ Rule 145 rescinded rule 133 , and the SEC took the position that a sale occurs when a plan of merger or transfer of assets is submitted for shareholder vote. The rule specifically defines a merger as a statutory merger or similar plan in which securities held by voting security holders will be exchanged for securities of any other corporation. ${ }^{102}$ Rule 145 defines a transfer of assets as one made as consideration for the issuance of securities of any other corporation under the terms of a pre-existmg plan for distribution of the issued securities. ${ }^{103}$ Rule 145 also limits the resale or exchange of securities by any party to a defined transaction. ${ }^{104}$ Thus, the rule

98. 17 C.F.R. $\$ 230.145$ (1980). See Heyman, Implications of Rule 145 Under the Securities Act of 1933, 53 B.U.L. Rev. 785 (1973), for a detailed analysis of rule 145. This Comment discusses only rule 145 's effects on spin-offs.

99. 17 C.F.R. $\$ 230.133$ (1980).

100. Rule 133 actually provided that there was no sale in those transactions. Section 5 requirements are based on the existence of a sale.

101. See SEC v. Spectruin, Ltd., 489 F.2d 535 (2d Cir. 1973); Comment, supra note 90, at 48891.

102. 17 C.F.R. $\$ 230.145$ (1980).

103. The rule states:

(a) Transactions Within this Section. An "offer," "offer to sell," "offer for sale," or "sale" shall be deemed to be involved, within the ineaning of Section 2(3) of the Act, so far as the security holders of a corporation or other person are concerned where, pursuant to statutory provisions of the jurisdiction under which such corporation or other person is organized, or pursuant to provisions contained in its certificate of incorporation or similar controlling instruments, or otherwise, there is submitted for the vote or consent of such security holders a plan or agreement for-

(1) Reclassifications. A reclassification of securities of such corporation or other person, other than a stock sphit, reverse stock spht, or change in par value, which involves the substitution of a security for another security;

(2) Mergers or Consolidations. A statutory inerger or consolidation or similar plan or acquisition in which securities of snch corporation or other person held by such security holders will becoine or be exchanged for securities of any other person, except where the sole purpose of the transaction is to change an issuer's domicile; or (3) Transfers of Assets. A transfer of assets of such corporation or other person, to another person in consideration of the issuance of securities of such other person or any of its affiliates, if:

(i) Such plan or agreeinent provides for dissolution of the corporation or other person whose security holders are voting or consenting; or

(ii) Such plan or agreeınent provides for a pro rata or similar distribution of such securities to the security holders voting or consenting; or

(iii) The board of directors or similar representatives of such corporation or other person, adopts resolutions relative to paragraph (a)(3)(i) or (ii) of this section within 1 year after the taking of such vote or consent; or

(iv) the transfer of assets is a part of a preexisting plan for distribution of such Id. securities, notwithstanding (a)(3)(i), (ii), or (iii) of this section.

104. Paragraph (c) of rule 145 , id., deems an underwriter to be any party to the specified transaction who sells securities acquired in connection with the transaction. Paragraph (d) allows 
strikes at the initial transaction in which the issuer's securities are transferred to the distributing corporation and at the subsequent resale of those securities.

Rule 145 is a practical deterrent to scheines seeking to avoid registration by the use of a spin-off. ${ }^{105}$ But the scope of the rule is limited in several respects. First, many spin-off transactions do not come withm rule 145 because they are not part of a merger or transfer of assets. ${ }^{106}$ Second, rule 145 does not affect the statutory exemptions, mcluding the private placement exemption. ${ }^{107}$ Finally, the rule does not deal with the spin-off of a wholly-owned subsidiary. ${ }^{108}$ Spin-offs of stock obtained in exempt transactions and spin-offs of wholly-owned subsidiaries are the two types of transactions most often subject to SEC noaction requests. ${ }^{109}$ In suin, rule 145 is not a pragmatic vehicle for ensuring the protection of the investing public that was intended by section 5 .

3. SEC No-Action Letters. Besides the affirmative actions to

a party not affliated with the issuer to resell securities if they have been held for two years and the issuer is a reporting company under the Securities Exchange Act of 1934. The issued securities may nonetheless be sold in accordance with rule 144, 17 C.F.R. $\S 230.144$ (1980), paragraphs (c) Current public information, (e) Limitation on the amount of securities sold, (f) Manner of sale, and $(g)$ Broker's transactions. These resale restrictions could be disastrous to a minority shareholder who receives stock in a spin-off. A recipient shareholder may desire or need to sell the stock he received. He may do so only by comphance with rule 145, under which he must wait two years, or counply with rule 144. Rule 144, in turn, requires current public mformation, but the minority shareholder cannot ensure that current public information is or will be available.

105. Even under rule 133 a transaction did not qualify for exemption if it was part of an illicit scheme at the time of the merger or sale of assets. SEC v. Spectrum, Ltd., 489 F.2d 535, 537 n.6 (2d Cir. 1973). See SEC v. Micro-Moisture Controls, Inc., 148 F. Supp. 558, 562 (S.D.N.Y. 1957), affd sub nom. SEC v. Culpepper, 270 F.2d 241 (2d Cir. 1959).

106. It is probable that a court would interpret rule 145 broadly to further the general purposes of the 1933 Act. The specific definitions of rule 145 transactions, however, preclude application of the rule to other types of transactions. See J.D. Simmons, Inc. v. Alliance Corp., 79 F.R.D. 547, 551 (W.D. Okla. 1978); no-action letter to Consohdated Oil \& Gas, Inc. (May 21, 1979). In fact, the typical spin-off scheme does not include a defined rule 145 transaction or the required shareholder vote. See SEC v. Datronics Eng'rs, Inc., 490 F.2d 250 (4th Cir. 1973), cert denied, 416 U.S. 937 (1974); SEC v. Harwyn Indus., 326 F. Supp. 943 (S.D.N.Y. 1971).

107. The Preliminary Note to rule 145 states: "Transactions for which statutory exemptions under the Act, including those contained in sections $3(\mathrm{a})(9),(10),(11)$, and $4(2)$ are otherwise available are not affected by Rule 145." 17 C.F.R. $\$ 230.145$ (1980). Section 4, 15 U.S.C. $\$ 77 d$ (1976), generally provides for exeinpt transactions. The private placement exemption is found in section 4(2) and rule 146, 17 C.F.R. \$ 230.146 (1980). See Parvin v. Davis Oil Co., 524 F.2d 112, 118 (9th Cir. 1975), cert. denied, 100 S. Ct. 1654 (1980).

108. A wholly-owned subsidiary is an operating busimess of the parent. It should be distinguished from the subsidiary in the Harwyn-type spin-off. In Harwyn the subsidiary was not wholly owned, and it was a shell until the infusion of assets by the merger with Harwyn.

109. See notes 110-38 infra and accompanying text. 
control spin-off transactions described above, ${ }^{110}$ the SEC has attempted to discourage spin-offs in its replies to no-action requests. ${ }^{11}$ An examination of the no-action letters concerning spin-offs reveals two dominant patterns of requests: ${ }^{12}$ the spin-off of a wholly-owned subsidiary ${ }^{113}$ and the spin-off of stock in another publicly traded corporation. ${ }^{114}$ The SEC's response generally focuses on three considerations: the independent, valid business purpose; the control relationship; and whether the distributed corporation is a reporting company under the 1934 Act. ${ }^{115}$

The first pattern of no-action letters concerns the proposed spin-off of a subsidiary corporation. ${ }^{116}$ In almost every instance the SEC was

110. See notes 84-109 supra and accompanying text.

111. This discussion examines no-action letters since February, 1974. For a discussion of earlier no-action letters, see Lorue, supra note 12, at 932-39.

A no-action letter consists of (a) one or more requests by corporations for a statement by the SEC that no action will be recommended to prevent a described transaction and (b) the SEC's replies to the requests.

112. Not included in the patterns are no-action requests from cautious corporations that wish to get SEC approval of a traditional stock dividend. See, e.g., no-action letter to Computer Capital Corp. (Sept. 19, 1977). These dividends do not require registration under section 5. See text accompanying notes 13-15 supra.

Several letters concerning special factual situations do not fall into any particular patteru. See, e.g., no-action letters to Reed Stenhouse Cos. (Aug. 13, 1979), Interprovincial Pipe Line, Ltd. (Apr. 16, 1979), and Inperial Oil, Ltd. (Feb. 26, 1979) (rcorganizations due to changes in the tax laws of Canada whereby class A and class B shares are consolidated into a single class); no-action letter to Cook Inlet Region, Inc. (Jan. 12, 1979) (an Alaska corporation formed pursuant to the Alaska Native Claims Settlement Act of 1971, 43 U.S.C.A. $\$ \S 1601-1628$ (West Supp. 1980), which exempted certain corporations from the 1933 Act); no-action letter to Flag-Redfern Oil Co. (June 19, 1978) (distribution of the company's interest in nonparticipating royalties to a trust for the benefit of only shareholders of record on a specified date); no-action letter to Affiliated Invs., Inc. (Oct. 3, 1977) (the corporation to be distributed was a bank subject to state and federal regulation but exempt under the transaction exemption provided by section c(a)(3), 15 U.S.C. $§ 77 c(a)(3)$ (1976)).

The dividend of royalty interests to a trust for the benefit of existing shareholders is a new method to avoid registration - a method the SEC has apparently accepted. Unfortunately, the SEC has not divulged the reasons for its acceptance. It is possible that the nontransferability of the trust interests was considered an adequate safeguard for investors, or that the royalty interest was not sufficiently large to warrant concern. The SEC, of course, did not necessarily agree with the corporation's no-sale theory. See also no-action letter to Telecor, Inc. (Apr. 12, 1979) (liquidating distribution into a trust for existing shareholders). But see no-action letter to International Royalty \& Oil Co. (Sept. 29, 1975).

113. See text accompanying notes $116-25$ infra.

114. See text accompanying notes 126-29 infra.

115. Many requests raise the factor of providing form $10-\mathrm{K}$ reports (4 FED. SEC. L. REP. $(\mathrm{CCH})$ १ी $31,102-03$ (1980)) to shareholders for adequate information and the features that distinguish the situation presented from prior case law that condemned spin-offs and no-action letters in which the SEC could not recommend no action.

116. No-action letters to Pioneer W. Corp. (Jan. 11, 1979); Jenoa, Inc. (Nov. 3, 1978); Caci, Inc. (Nov. 14, 1977); Brandywine Raceway Ass'n (June 27, 1977); Trans Graphic, Inc. (Apr. 12, 1976); Capital Sav. \& Loan Ass'n (Dec. 15, 1975); Terracor (Nov. 24, 1975); International Royalty 
unable to conclude that it would not recommend enforcement. ${ }^{117}$ In every case, the requesting coinpany controlled the subsidiary but made at least a colorable claim that there was an independent, valid business purpose for the spin-off. ${ }^{118}$ The SEC distinguished the subsidiary spimoff from the permissible spim-off of stock of a publicly traded corporation by noting that the subsidiaries were not reporting companies. ${ }^{119}$ It was to no avail for the parent to promise the SEC that the subsidiary would register under the 1934 Act $^{120}$ or to distinguish prior case law and no-action letters ruling against unregistered spin-offs. ${ }^{121}$ Neither would the SEC accept the distribution of information to shareholders

\& Oil Co. (Sept. 29, 1975) (55\% owned); Elba Syss. Corp. (Apr. 29, 1974); Chicago Rawhide Mfg. Co. (Feb. 11, 1974).

117. Two no-action letters presented the SEC with unusual spin-ofls of wholly-owned subsidiaries-no-action letters to First Bancshares of Florida, Inc. (Aug. 27, 1979); and Unitcd Van Lines, Inc. (Aug. 6, 1979). The letter to First Bancshares of Florida, Inc., involved a sale of a substantial number of the parent's banking and non-banking subsidiaries. The businesses retained were consolidated into one subsidiary. At the same time tbat the remaining assets were exchanged for a registered offering of preferred stock, the operating subsidiary was spun off pro rata. The newly spun-off corporation would maintain the reporting status of the dissolved parent. In the letter to United Van Lines, Inc., the parent sought to distribute its foreign-controlled insurance subsidiary for tax reasons. The stock of the subsidiary would not be traded actively. The shareholders were agents of United Van Lines who were familiar with the company's operations and received financial information. Their stock was sold back only to United Van Lines.

118. For exanple, Pioneer Western Corp. proposed the spin-off out of fear that a merger attempt by another corporation would terminate, by a change in control of Pioneer Western Corp., nuanagement contracts held by the distributed coinpany with three investment companies. In the Caci, Inc., situation the distribution was to enhance business opportunities for its foreign subsidiary. The Trans Graphics, Inc., dividend of stock was the result of a difference of opinion between two management control groups. Terracor wanted the spin-off to allow the subsidiary to obtain financing unhampered by the financial difficulties of the parent. Jenoa, Inc., gave a more questionable busmess reason, asserting that it sought an independent and improved framework for management but not statimg any serious manageinent conflicts.

119. Section 12 of the 1934 Act, 15 U.S.C. $\$ 78 /(1976)$, requires registration with the SEC on a periodic basis before a security can be traded lawfully. Subsection (g) specifies the mimimal conditions necessary to require registration. Basically, the corporation must have total assets in excess of $\$ 1,000,000$ and more than 500 shareholders. Reports must be filed yearly (form 10-K (4 FED. SEC. L. REP. (CCH) If 31,102-03 (1980))) and quarterly (form 10-Q (4 FED. SEC. L. REP. (CCH) If 31,031 (1980))). The reports provide the public with substantial information about the reporting company. A wholly-owned subsidiary is obviously not reporting under the Securities Act of 1934, and the reporting status of the parent is not applicable. See, e.g., no-action letters to Pioneer W. Corp. (Jan. 11, 1979); Jenoa, Inc. (Nov. 3, 1978); Caci, Ine. (Nov. 14, 1977); and Brandywine Raceway Ass'n (June 27, 1977). Compare no-action letter to Consolidated Oil \& Gas, Inc. (May 21,1979 ) (the parent reinams in control but the subsidiary is a reporting company) with no-action letter to International Royalty \& Oil Co. (Sept. 29, 1975) (the distributing company owned 55\%, but a registration statement for a separate $30 \%$ had been filed).

120. See no-action letters to Jenoa, Inc. (Nov. 3, 1978); Trans Graphics, Inc. (Apr. 12, 1976); and Elba Systems Corp. (Apr. 29, 1974); cf. International Royalty \& Oil Co. (Sept. 29, 1975) (effective registration statement).

121. See, e.g., no-action letter to Pioneer W. Corp. (Jan. 11, 1979). 
by a proxy or otherwise. ${ }^{122}$ In fact, the SEC specifically noted value to the parent in one instance, ${ }^{123}$ which value would mandate registration under section 5. Although these no-action letters contain hittle reasoning to support the SEC's position, ${ }^{124}$ it is clear that the SEC will not permit the spin-off of a subsidiary if the subsidiary is not a reporting company. ${ }^{125}$

The second pattern of no-action letters consists of situations in which a public corporation owned stock in another public corporation-in every case, a reporting company. ${ }^{126}$ In general, the corporation in question sought to distribute the stock pursuant to an independent, valid business purpose, and no control relationship existed.127 There was, however, no uniformity in the circumstances surrounding the acquisition of the shares. ${ }^{128}$ Although the SEC initially was reluctant to allow this pattern of spin-offs, it made a dramatic change of pohicy in September, 1975,129 mdicatimg it would not thereafter recommend enforceinent actions. Hence, as long as there is no control relationship, a public corporation that owns stock in a reporting company can obtain a no-action response.

122. See, e.g., no-action letters to Pioneer W. Corp. (Jan. 11, 1979); Jenoa, lnc. (Nov. 3, 1978); and Caci, Inc. (Nov. 14, 1977).

123. No-action letter to Caci, lnc. (Nov. 14, 1977) (tax benefits accruing to the parent).

124. A no-action letter states the facts of the situation presented and whether no action will be recommended based on those facts. Occasionally the letter also inentions the conclusion of the requesting corporation. The SEC does not bind itself by stating any reason for its decisions.

125. The importance of reporting company status is the necessity that the company file with the SEC information relevant to the operations and earnings of the company. That information is subject to public inspection.

126. No-action letters to Consolidated Oil \& Gas, Inc. (May 21, 1979); Western Digital Corp. (Dec. 1, 1978); Imoco-Gateway Corp. (Oct. 30, 1978); Amcrican Television \& Communication Corp. (July 27, 1978); Pogo Producing Co. (Dec. 27, 1977); 20th Century Corp. (Nov. 7, 1977); Vipont Mining Co. (Sept. 6, 1977); Cresson Consol., Inc. (July 13, 1977); Fiftl Ave. Capital Assocs. (July 11, 1977); Rand Capital Corp. (May 12, 1977); Helmerich \& Payne, Inc. (Feb. 24, 1977); Wien Air Alaska, Inc. (Jan. 17, 1977); Macrodata Corp. (May 5, 1976); Younker Bros. (Oct. 8, 1975); American Express Co. (Sept. 26, 1975); Transairco, Inc. (July 5, 1974); National Petroleum Corp. (June 24, 1974); $c$. International Royalty \& Oil Co. (Sept. 29, 1975) (55\% owned by the distributing corporation and had an effective registration statement).

127. But see no-action letter of Consolidated Oil \& Gas, Inc. (May 21, 1979).

128. The methods of acquisition included the private purchase of unregistered shares. See noaction letters to American Television \& Communications, Inc. (July 27, 1978); Fifth Ave. Capital Assocs. (July 11, 1977); Rand Capital Corp. (May 12, 1977). Unrcgistered shares were also acquired by less common methods. See, e.g., Western Digital Corp. (Dec. 1, 1978) (breach of contract settlement); Dorsett Educ. Syss., Inc. (July 20, 1978) (a default where stock was pledged for debt); 20tll Century Corp. (Nov. 7, 1977) (received stock in exchange for part of a business). Some distributing companies formed corporations which later went public. See, e.g., Pogo Producing Co. (Dec. 27, 1977); Vipont Mining Co. (Sept. 6, 1977). Occasionally, registered stock was purcliased. American Express Co: (Sept. 26, 1977) (tender offer). In one instance, the stock to be distributed was acquired in a public rights offering. Consolidated Oil \& Gas, Inc. (May 21, 1979).

129. No-action letter to American Express Co. (Sept. 26, 1975). 
The response of the SEC to no-action requests concerning spinoffs lias been adequate in liglit of the confusing state of the law. ${ }^{130}$ Spin-offs of a company for which adequate information has not been publicly disseminated prior to the distribution is contrary to the spirit of the Securities Act of 1933 and should be prevented. ${ }^{131}$ On the other hand, any attempt to prevent "conventional spin offs"132 where the spin-off involves a valid business purpose, no control relationship, and sufficient public information is arguably improper. Thus, the SEC compromised by permitting spm-offs if adequate public information is on file with the Commission on 1934 Act registration forms. ${ }^{133}$

Although this compromise may be advisable, especially in view of the ingenuity of securities lawyers and the limited resources of the $\mathrm{SEC}$, tle response of the Commission in no-action letters provides little guidance in the search for value in the spin-off. A valid business purpose does not remove value from a transaetion, nor does lack of a valid business purpose add value. ${ }^{134}$ The control relationship is also irrelevant to value. 135 Ownership of a controlling interest by a distributing corporation does not cause value to flow from the recipient share-

130. The SEC caused the confusion by failing to reject the generally held belief that there is no value given in a spin-off. See SEC v. Harwyn Indus., 326 F. Supp. 943, 945 (S.D.N.Y. 1971); see text accompanying notes 16-19 supra.

131. See text accompanying notes 1-5 supra. Reports filed by the parent pursuant to the Securities Exchange Act of 1934 are not adequate to inform the public concerning a subsidiary, especially if the subsidiary is wholly-owned and the financial statements are consolidated. See form 10-K, item 4, 4 FED. SEC. L. REP. (CCH) I 31,103 at 22,054 (1980). See note 134 infra and accompanying text.

132. See text accompanying note 89 supra.

133. Compare text accompanying notes $116-25$ supra with text accompanying notes $126-32$ supra. A reporting company by definition furnishes substantial mformation to the public market. See note 119 supra and accompanying text.

134. See text accoinpanyimg notes $72-76$ supra. Of course, every no-action request will statc a valid business purpose. It is hard to conceive of a corporation requesting a no-action response after stating that the purpose of the transaction is to evade registration illegally.

135. Because of the statutory definition of an issuer in section 2(4), 15 U.S.C. $\S 77 b(4)$ (1976), a control relationship is critical to the ultimate legality of a transaction. The importance of the control relationship arises when the distributed stock is sold by means of a section 4(1) exempt transaction, 15 U.S.C. \& 77d(1) (1976). Section 4(1) exempts transactions in which the seller is not an issuer, underwriter, or dealer. If the distributing corporation is in a control relationship with the distributed corporation, the recipient shareholders may be deemed underwriters because of their indirect participation in an undertaking to sell stock for an issuer in connection with a distribution. See section 2(11), 15 U.S.C. § 77b(11) (1976); Smith v. Pharo, 621 F.2d 656 (5th Cir. 1980). The control relationship would thereby obviate the exempt-transaction status of a sale. The innocent shareholder may not be subject to suit. See Long, supra note 51, at 346-50. His sale, however, would not be under the section 4(1) exemption, and the transaction from its inception could be prohibited. Rather than assisting the search for value, the control relationship allows the prohibition of a transaction without a finding of value. 
holders to the distributing corporation. ${ }^{136}$ Furthermore, not every spinoff permitted by an SEC no-action letter involved a valid purpose and the lack of a control relationship. ${ }^{137}$ The essential consideration, rather, was whether the corporation whose stock was distributed was a reporting company. ${ }^{138}$

The SEC cannot make law with no-action letters. ${ }^{139}$ The Supreine Court has made this clear, stating, "The rulemaking power granted to an administrative agency charged with the administration of a federal statute is not the power to inake law. Rather, it is " "the power to adopt regulations to carry into effect the will of Congress as expressed by the statute." " 140 Hence, the important inquiry when considering the distributed corporation's reporting status under the 1934 Act is not whether the reporting status is an adequate determinant for policy reasons, ${ }^{141}$ but whether it is an appropriate criterion for resolving an issue under the 1933 Act. Section 5, which is the existing legislation concerning registration, requires registration of a security. ${ }^{142}$ Thus, a corporation with an effective registration statement on file for previously sold securities (common stock, for example) inust, under section 5, file another registration statement and otherwise comply with that provision

136. In fact, the court found value in SEC v. Harwyn Indus., 326 F. Supp. 943, 954 (S.D.N.Y. 1971), even though the distributing corporation was not a controlling shareholder.

137. Compare no-action letters to Consolidated Oil \& Gas, Inc. (May 21, 1979) and American Television \& Communication Corp. (July 27, 1978) with no-action letter to American Express Co. (Sept. 26, 1975). But see no-action letter to First Bancshares of Florida, Inc. (Aug. 27, 1979).

In several requests, the purpose of the dividend was the hiquidation of the distributing company. See, e.g., Imoco-Gateway Corp. (Oct. 30, 1978). Liquidation by itself may not be an appropriate business purpose. See Sec. Act Release No. 4982 (July 2, 1969), 17 C.F.R. § 231.4982 (1980); $c f$. Bromberg, supra note 11 (liquidation was assumed to be a valid purpose). The purpose of the liquidation is the inore important inquiry.

138. See no-action letter to First Bancshares of Florida, Inc. (Aug. 27, 1979). Reporting status is also a method of coinplying with rule 15c2-11. See text accompanying notes 95-97 supra. See also no-action letter to Imperial-American Resources Fund, Inc. (Mar. 27, 1977).

139. The SEC enjoys rulemaking authority. See text accompanying notes 77-78 supra. Moreover, the authority to promulgate rule 145 and rule $15 \mathrm{c} 2-11$ is not questioned. The ability of the SEC to imterpret properly the registration requirements of the 1933 Act in no-action letters, however, has been questioned. See International Bhd. of Teamsters v. Daniel, 439 U.S. 551,566 n.20 (1979).

140. Ernst \& Ernst v. Hochfelder, 425 U.S. 185, 213-14 (1976) (citations omitted) (quoting Dixon v. United States, 381 U.S. 68, 74 (1965) (quoting Manhattan Gen. Equip. Co. v. Commissioner, 297 U.S. 129, 134 (1936))).

141. See text accompanying notes 130-33 supra.

142. For example, section 5 begins, "Unless a registration statement is in effect as to a security." 15 U.S.C. $\$ 77 \mathrm{e}$ (a) (1976) (emphasis added). Section 3, 15 U.S.C. \$\$ 77c (1976), exempts certain classes of securities from registration. Section 4, 15 U.S.C. $\$ 77$ d (1976), generally exempts specific transactions, but not securities. The 1934 Act, on the other hand, generally seeks registration of compamies. See section 13, 15 U.S.C. $\$ 78 \mathrm{~m}$ (1976); form 10-K, 4 FED. SEC. L. REP. (CCH) ITा 31,102-03 (1980). 
in order to sell additional securities. It does not matter that the corporation is required by the 1934 Act to file periodic reports. ${ }^{143}$ The criteria the SEC einployed in no-action replies, however, would allow a reporting company to sell its stock to another public company without registration; the stock could then be distributed as a dividend im a spinoff. ${ }^{144}$ Furthermore, the SEC criteria would allow a corporation to spin off the shares of a previously wholly-owned subsidiary if the subsidiary has sold stock to the public and become a reporting company. ${ }^{145}$ In permitting these unregistered transactions, the SEC has failed to consider the intent and language of the 1933 Act as well as the informational needs of the investors receivmg the distributed stock.

The proposed American Law Institute Federal Securities Code takes an approach different from the current legislation by requiring registration of corporations rather than securities. ${ }^{146}$ Even if the SEC is anticipating this proposed Code in its no-action letters, ${ }^{147}$ it cannot legitimately use a company's 1934 Act reporting status to excuse that coinpany's spin-offs of unregistered securities. If the position taken by the American Law Institute is in the best imterests of investors, then Congress, not the SEC, must change the existing laws.

The 1933 Act requires registration of a security prior to its mitial sale to the public. Under section 5 the proper imquiry is whether the particular security subject to the dividend distribution has a registra-

143. The 1933 Act does not have an exemption for companies reporting under the 1934 Act.

144. See no-action letters to 20th Century Corp. (Nov. 7, 1977); Cresson Consol., Inc. (July 13, 1977); Fifth Ave. Capital Assocs., (July 11, 1977).

145. See no-action letters to American Television \& Communication Corp. (July 27, 1978); Pogo Producing Co. (Dec. 27, 1977); Vipont Mining Co. (Sept. 6, 1977).

146. ALI FED. SEC. CODE, $\$ \$ 401-406$ (1980). See id. xxv-xxxvii. The code would also answer the value issue in spin-ofis by defining a sale to include a dividend of stock in another corporation. Id. $\$ 202(143)(\mathrm{A})$, (F).

The SEC has already begun a shift toward coinpany registration. See, e.g., Scc. Act. Release Nos. 6232 \& 6235 (Sept. 2, 1980), [1980 Current Binder] FED. SEC. L. REP. (CCH) II 82,648 and 82,649. A recent preliminary prospectus (form 5-16, 2 FED. SEC. L. REP. (CCH) 7291 (1980)) relating to an offering of $\$ 6,000,000$ worth of shares of common stock of Virginia Electric \& Power Co. (Oct. 31, 1979), incorporated by reference the company's form 10-K report (4 FED. SEc. $L$. REP. (CCH) II 31,102-03 (1980)) and form 10-Q reports (4 FED. SEC. L. REP. (CCH) \ 31,031 (1980)), and its most recent proxy statement. (schedule 14B, 17 C.F.R. $\$ 240.14 a-102$ (1980)) The document then summarized other information and financial statements considered relevant to investor decisions. Presumably, this abbreviated prospectus is substantially less expensive than security registration, yet it provides purchasers with all the necessary information. See 15 U.S.C. $\S 77 \mathrm{j}(\mathrm{a})(4)$ (1976). Unfortunately, private investors who must make investment decisions (as opposed to valuation decisions) have limited access to the incorporated documents. These private investors are the ones who need the inost protection and to whom the securities laws are directcd.

147. The issuer registration provisions were contamed in tentative drafts of the code. ALI Fed. SEC. Code (tent. drafts nos. 1-3, 1974). Cf. Jofinson v. Wiggs, 443 F.2d 803, 806 (5th Cir. 1971) (no duty to disclose when the information is in the public domaim). 
tion statement on file and in effect. Only when the security is subject to an effective registration statement can a corporation distribute it as a dividend. ${ }^{148}$ As a practical matter, however, unless value can be found in a spin-off, the SEC's position must suffice for the protection of investors.

\section{ANalyzing Value In the Spin-OfF TRansaction}

In the search for value in a spin-off transaction, the proper approach is to look for economic worth flowing from the shareholder stock recipient to the distributing corporation. ${ }^{149}$ Because of the difficulty of doing so, however, ${ }^{150}$ the courts, $\mathrm{m}$ the few instances in which they have sought to find value, have not taken the proper approach. In one instance, the court traced value from those in the market to whom the recipient shareholder sold the spun-off stock. ${ }^{151}$ In another case, the court identified value flowing to the distributing corporation, without identifying the source of the value. ${ }^{152}$

The purpose of the registration requirement of the 1933 Act is to protect those who receive stock, including shareholders. ${ }^{153}$ That purpose can be seen in the primary safeguard provided to compensate for section 5 violations-recovery of "consideration paid." 154 If the share-

148. Compare no-action letter to American Express Co. (Sept. 26, 1975) with no-action letter to American Television \& Communication Corp. (July 27, 1978). A corporation can purchase, in the open market, stock in another corporation and then spin off that stock to shareholders. The question arises whether the spin-off of shares purchased in the inarket is different from a spin-off of the same type of shares acquired in a private placement. From a policy standpoint there is no difference. The recipient shareholders are offered the saine information with the same access to it; they make the same investinent decisions. On the other hand, the 1933 Act does differentiate between these spin-off situations. See note 135 supra and accompanying text. Cf. rule 144(e)(2), 17 C.F.R. $\$ 230.144(\mathrm{e})(2)(1980)$ (allowing an unlimited number of shares to be sold by a nonaffiliate, provided there is public information).

149. Cf. Bromberg, supra note 11, at 4 ("Even if it be thought that the shareholder gives 'value,' it can hardly be true that the corporation receives 'value' [in a liquidating distribution]").

150. See text accompanying notes 16-22 supra.

151. SEC v. Harwyn Indus., 326 F. Supp. 943, 954 (S.D.N.Y. 1971).

152. SEC v. Datronics Eng'rs, Inc., 490 F.2d 250, 253-54 (4th Cir. 1973), cert. denied, 416 U.S. 937 (1974).

153. The fact that the House originally considered it necessary to include an exemption for stock dividends indicates that the protections of the 1933 Act reach corporate shareholders. See note 14 supra and accompanying text.

154. Section 12, 15 U.S.C. $77 /$ (1976), provides in part:

Any person who-(1) offers or sells a security in violation of section $77 \mathrm{e} . .$. , shall be hable to the person purchasing such security from him, who may sue either at law or in equity in any court of competent jurisdiction, to recover the consideration paid for such security with interest thereon, less the amount of any income received thereon, upon the tender of such security, or for damages if he no longer owns the security.

(Emphasis addcd.) The shareholder is also protected by the antifraud provisions, especially section 17 of the 1933 Act, 15 U.S.C. $\$ 77 q$ (1976), and section 10(b) of the 1934 Act, 15 U.S.C. $\S 78 j(b)$ (1976). But see Smith v. Pharo, 621 F.2d 656 (5th Cir. 1980). It may be easier to show a 
holder does not give value (consideration) for the stock received, then he cannot be protected by recovery of "consideration paid." At the same time, this shareholder may be subject to liability if he sells the dividend. ${ }^{155}$ Congress, however, could not and did not intend to allow such an unjust situation; instead, the spin-off of unregistered securities involves a sale because the recipient shareholders give value.

Three theories are conventionally given to negate the finding of a sale im a spin-off. First, the shareholder takes no individual action..$^{156}$ Yet a shareholder should be entitled to the protcctions of the 1933 Act regardless of whether he chooses to receive the stock. Indeed, a shareholder forced to accept a portfolio security without adequate information about the issuing corporation is more deserving of protection than an individual who has an opportumity to make an investment decision, even though the latter investor likewise lacks adequate mformation. ${ }^{157}$ A second theory is that a dividend of stock of another corporation inerely perfects the pro rata ownership that the shareholders already enjoy. ${ }^{158}$ Such an interpretation of the transaction, however, does not bring it outside the provisions of the 1933 Act $^{159}$ and thus does not negate the finding of a sale in a spin-off. The third theory claims that under the 1933 Act a spin-off is indistinguishable from a stock divi-

sale under section 10(b). See International Controls Corp. v. Vesco, 490 F.2d 1334 (2d Cir.), cert. denied, 417 U.S. 932 (1974).

155. See note 135 supra and accompanying text. The value paid by a shareholder may be his potential liability if he should sell.

156. This theory has its origin in rule 133, 17 C.F.R. $\$ 230.133$ (1980), which stated that no sale occurs when shareholders take corporate action by voting. See Bromberg, supra note 11, at 67. But see rule 145, 17 C.F.R. $\$ 230.145$ (1980), which replaced rule 133 in 1973 . Now a sale is deemed to be involved when shareholders vote for a reclassification, merger, or consolidation, and transfer of assets. See text accompanying notes 98-109 supra.

157. At the same time, it could be argued that the shareholder made his investment decision with adequate information when he purchased stock in the distributing corporation. The argument assumes either that the distributing corporation owned the stock distributed prior to the shareholder's investment decision or that the action of inanagement subsequent to the investment decision is a risk incident to shareholder status. On the other hand, the earnings flow of the distributing corporation may be subject to an unexpected increased risk because of the distribution of a diversifying asset. This increased risk can be accomplished without a shareholder vote.

158. See SEC v. Harwyn Indus., 326 F. Supp. 943 (S.D.N.Y. 1971).

159. Section 3(a)(9), 15 U.S.C. \& 77c(a)(9) (1976), provides that the 1933 Act does not apply to "[a]ny security exchanged by the issuer with its existing security holders exclusively." Congress thus must have considered such a reorganization to be otherwise within the coverage of the 1933 Act. A spin-off is not exempted by section 3(a)(9), for it is not an exchange between the issuer and its shareholders. Cf. House Report, supra note 14 (the joint committee removed an exemption for stock dividends because stock dividends were not within the coverage of the Act even without the exeinption). In addition, rule 145, 17 C.F.R. $\$ 230.145$ (1980), deems a "sale" to be imvolved when shareholders vote for a reclassification other than a stock sphit, a reverse stock split, or a change in par value, and when there is a substitution of one security for another. A change in the form of ownership falls under the 1933 Act's registration provision unless specifically exempted. 
dend. ${ }^{160}$ This last theory may be the most persuasive. ${ }^{161}$ In both a spin-off and a stock dividend, the shareholder receives additional stock. In both situations, the stock is paid out of the corporation's retamed earnings. In addition, the shareholder does not pay cash for either type of dividend. Thus, to the shareholder, a spin-off and a stock dividend may appear to be the same; this appearance is misleading, however, because it hides the true substance of spm-offs-direct ownership of another corporation by the recipient shareholders.

A spin-off distributes corporate assets and is thus a reorganization, separating the distributed assets from the corporation. ${ }^{162}$ To the extent the assets are distributed, the shareholders' equity in the distributing company is diminished. ${ }^{163}$ The ability of the distributing corporation to pay dividends in the future is diminished as well. ${ }^{164}$ Furthermore, the risk of the distributing corporation mcreases because its income stream is more concentrated. ${ }^{165}$ More important, the value of the dis-

160. See text accompanying notes 11-19 supra.

161. See the comments of Judge Mansfield in SEC v. Harwyn Indus., 326 F. Supp. 943, 952-53 (S.D.N.Y. 1971).

162. See, e.g., In re Whiteacre's Will, 208 Minn. 286, 293 N.W. 784 (1940); City Bank Farmers' Trust Co. v. Ernst, 263 N.Y. 342, 189 N.E. 241 (1934).

The separation of assets or busimesses is one of the reasons for the spin-off remedy for antitrust violations. See, e.g., United States v. United Technologies Corp., 466 F. Supp. 196, 201-02 (N.D.N.Y. 1979). The potential tax advantage or detriment due to a distribution of appreciated or depreciated stock has not been examined. In addition, research revealed no study that examines the information content of a spin-off in lieu of a cash dividend. At the same time, an investor may want to make an investment decision on the stock spun off based upon his own investment needs, risk adversion, and diversification plan.

163. Portfolio securities are carried on the books of the corporation at the lower of market value or cost. See Haried \& Smith, Accounting for Marketable Equity Securities, 143 J. AccounTANCY 54 (1977). Subsidiaries are carried at cost ou consolidated statements. The distribution of portfolio securities is recorded at the fair market value of the securities. Any gain or loss on the securities is recognized. APB OpINION No. 29 (1973). Whether the gam or loss is an extraordinary item on the income statement is determined by the unusual nature and imfrequency of occurrence of the spin-off. Id., No. 30, IT 19-24. Accounting for a spin-off of a subsidiary is based on the recorded amount of the asset distributed. $I d$., No. $29, \eta 21$. A spin-off thus reduces shareholders' equity by the fair market value of portfolio securities or the cost of (or investment in) a subsidiary. See APB Statement No. 4, II 182 (1970). Because the transaction is a dividend, the debit is to earned surplus. See ABA-ALI MODEL Bus. CoRP. ACT \& 45(a) (1971).

164. The distributing corporation has less earned surplus from which to pay dividends in the future. For most larger corporations, this consideration is academic because there is a more than adequate earned surplus.

165. This discussion assumes that the proper method of stock valuation is the present value of future benefits received from the investment. Risk imcreases as the range of possible outcomes increases. The range of possible outcomes depends on the range of possible dividend payments, which in turn depends on the range of future earning streams of the corporation. The range of possible earnings can grow by the diversification of earning streams. Conversely, the possible earnings of a corporation decrease with the elimination of assets that produce separate earning streams. If both the variance of earning streams and, correspondingly, the risk increase, then investors will require a greater return to induce their investment in the corporation. The firm's 
tributing corporation is diminished by the earning power of the assets distributed.166 A shareholder who receives stock in a spin-off thus owns two securities-stock in the distributing corporation, which stock is now worth less, ${ }^{167}$ and stock in some other corporation. The other corporation has different total earning streams, different dividend-paying capacity, and different risks. The shareholder gives up value in the distributing corporation when he receives the distributed stock. For exainple, assume corporation $X$ owns 10,000 shares of corporation $Y$ worth $\$ 100,000$. $X$ has 100,000 shares outstanding and has a book value of $\$ 500,000$. $Y$ pays a dividend to $X$, after tax, of $\$ 10,000$, and $X$ has total earnings of $\$ 100,000$. Assuming the market capitalizes $X$ and $Y$ equally, $X$ 's total stock is selling at $\$ 1,000,000$. A stock distribution of one share of $Y$ for every 10 shares of $X$ would: (1) reduce the book value of $X$ to $\$ 400,000$, (2) reduce the earnings of $X$ to $\$ 90,000$, (3) reduce the total value of $X$ s stock to $\$ 900,000$, (4) reduce by $\$ 10,000$ the ability of $X$ to pay future dividends, (5) increase $X$ 's business risk by decreasing its diversification, and (6) increase $X$ 's debt-to-equity ratio. Although the example is simplified, it illustrates that shareholders of $X$ inust give up considerable value to receive the share of $Y$. The fact that the recipients of the stock did not give cash or other value to the distributing corporation is irrelevant to the protective scheine of the 1933 Act. ${ }^{168}$

A stock dividend, in contrast to a spin-off, does not reduce total shareholders' equity, nor does it reduce the earning power of the corporation. A stock dividend is a bookkeeping adjustunent, declaring a portion of accuinulated earnings (represented by the dividend) to be permanently appropriated to capital. ${ }^{169}$ The corporation gives up noth-

discount rate reflects this greater expected return. A higher discount rate (other things being equal) results in a lower stock price.

166. A corporation to be distributed has either a potential for carnings which would flow to the distributing corporation or the potential for capital appreciation which would produce a future gain for the distributing corporation. The earnings of the distributing corporation could be in the form of revenues from a subsidiary's business or in dividends paid. The distributing corporation would then have a greater ability to pay dividends. Conversely, a decrease in earnings by the amount contributed by the distributed asset before its distribution would decrease the distributor's ability to pay dividends. If a stock is valued at the present value of future dividends, that value inust decrease if the potential for future dividends decreases.

167. Stock in the distributing corporation should be worth less even though the combined value of the distributing corporation and the distributed corporation may be more than the value of the distributing corporation before the spin-off.

168. See text accompanying notes 153-55 supra. The corporation does receive the benefit of not paying out cash in the dividend; it can use that cash to improve future earnings.

169. Eisner v. Macoinber, 252 U.S. 189, 211 (1920); In re Estate of Jaffer, 58 Misc. 2d 948, 297 N.Y.S.2d 655, 659 (Sur. Ct. 1969). In Stipe v. First Nat'l Bank of Portland, 208 Or. 251, 301 P.2d 
ing and the shareholder receives nothing, ${ }^{170}$ the stock dividend is a mere change in evidence of ownership. ${ }^{171}$ Moreover, the only effect on the shareholder is a reallocation of cost to the total shares held; ${ }^{172}$ the shareholder does not indirectly give up a source of corporate earning power. The corporation's ability to pay future dividends is, of course, reduced, but that reduction is the purpose of the stock dividend, as opposed to a stock sphit ${ }^{173}$ (though from the viewpoint of the shareholder, a stock dividend is very similar to a stock split). ${ }^{174}$

Unlike a stock dividend, a spin-off is a distribution of a security for value-a sale. ${ }^{175}$ The consideration paid by the shareholder is the decrease in the value of the distributing corporation. The 1933 Act

175 (1956), the Supreme Court of Oregon applied generally accepted accounting and tax practices in describing a stock dividend:

A stock dividend takes nothing from the property of the corporation and adds nothing to the interests of the shareholders. The property of the corporation is not diminished. The stockholder's interests are not mcreased. Their proportional imterests remain the same. The only change is in the evidence which represents a given stockholder's interest, that is, the new shares representing the same proportional interest that the original shares represented before the issue of the stock dividend. In short, the corporation is no poorer and the stockholder is no richer than they were before. A stock dividend is, therefore, not in any true sense a dividend at all. Its issuance is, in the last analysis nothing more than an incident or process in corporation bookkeeping.

Id. at 274, 301 P.2d at 186. See SEC Accounting Research Bulletin No. 43.

170. Eisner v. Macomber, 252 U.S. 189 (1920); Stipe v. First Nat'1 Bank of Portland, 208 Or. 251, 301 P.2d 175 (1956).

171. City Bank Farmers' Trust Co. v. Ernst, 263 N.Y. 342, 189 N.E. 241 (1934).

172. Id. Until there is a severance of assets there is no income. See generally Eisner v. Macoinber, 252 U.S. 189 (1920); $c f$. I.R.C. $§ 301$ (dividends of stock income).

173. Both a stock split and a stock dividend in essence give the shareholder a greater number of shares for the same proportionate imterest in the corporate enterprise. A stock dividend causes the corporation to capitalize retained earnings or to transfer the fair market value of the dividend from retained earnings to permanent capital. A stock split does not entail a similar transfer because the transaction is "prompted mainly by a desire to increase the number of outstanding shares for the purpose of effecting a reduction in their unit market price . . . " CoMm. on ACCounting Procedure, Accounting Research Bulletins, No. 43, ch. 7B, $\ 2$ (1953).

174. ARB No. 43 defines a stock dividend as an issuance by a corporation of its own common stock promptcd by a desire to give the shareholders some evidence of their interest in accumulated corporate earnings. Id., I 1 . The evidence of corporate earnings is provided without a distribution of cash or other corporate assets which the directors beheve should be retamed in the business. A stock split is also an issuance by a corporation of its own common stock, but is prompted by a desire to increase the number of outstanding shares so as to reduce the market price of the shares, thereby obtaining wider distribution and improved marketability of the stock. Id., $\mathbb{2} 2$. The distinction for accounting purposes is the increase in the number of shares issued. If the increase is less than $20 \%$ to $25 \%$, the transaction is presumed to be a stock dividend. Id., I 13, 1516. The issuance of sliares to common stockholders in a close corporation is always a stock split. Id., I 12.

There is no particular difference in stock price behavior between shares subject to stock dividends and shares subject to stock splits. See Millar, Split or Dividend: Do the Words Really Matter?, 52 ACCOUNTING Rev. 52 (1977).

175. Section 2(3) of the Securities Act of 1933, 15 U.S.C. $\$ 77 b(3)$ (1976). 
protects this value, ${ }^{176}$ which the shareholder surrenders in order to receive stock in the other corporation. ${ }^{177}$ If the shareholder sells the unregistered security, the corporation is liable for damages, including the shareholder's liability to the buyer. ${ }^{178}$ In addition, the Securities and Excliange Commission has authority to prevent spin-offs of unregistered securities when the spin-off diminishes the value of the distributing corporation. ${ }^{179}$ If the shareliolders' giving of value is recognized in a spin-off, the present SEC position in no-action letters on subsidiary spin-offs would not change; however, the present position on spin-offs of stock of corporations reporting under the 1934 Act would be substantially altered. The validity of a spin-off would not turn on the company's 1934 Act reporting status, but on whether the distributed stock was subject to an exemption or was registered in accordance with the 1933 Act prior to the spin-off.

Ironically, the nost difficult spin-off to prevent under this proposed concept of value would be the very spin-off that most violates the 1933 Act's purposes. A corporation desiring to go public can give another corporation some of its stock, ${ }^{180}$ which is simultaneously spun off. The recipient corporation, which gives nothing for the stock, is not diminished in value after the spim-off, so the spin-off does not cause the sliareholder to part with value. At the same time, the spin-off contemplates an active trading inarket in the distributed stock. ${ }^{81}$ This type of transaction, however, will not escape registration requirements: It can be analyzed simply as an attempt to violate the 1933 Act, ${ }^{182}$ without reference to the spin-off. Because the substance of the transaction is the

176. Section 12 , 15 U.S.C. $\$ 77 l(1976)$.

177. In the hypothetical in the text accompanying notes 167-68 supra the consideration would be paid on the $X$-dividend date. The $X$-dividend date is the date the shareholders are legally entitled to the dividend and the price is reduced to reflect the obligation of the distributing corporation. The SEC could argue, however, that the consideration is paid, for purposes of a Securities Act violation, on the day the spin-off is declared. It is the declaration date on which the corporation becomes obligated to pay the dividend in stock.

178. Section 12, 15 U.S.C. $\S 77 l$ (1976), provides for damages whether or not the security is still owned by the recipient shareholder. The sale by the recipient shareholders and the subsequent hability are foreseeable by the distributing corporation, so imposition of habihty in such cases is reasonable.

179. The SEC has authority to bring an action to enjoin any activity that has violated or will violate any provision of the Securities Act of 1933. Section 20, 15 U.S.C. \& 77t(b) (1976).

180. A pure gift of stock by an issuing corporation is fraudulent and a violation of state law. See, e.g., MODEL Bus. CORP. ACT $\S 17$ (1971). Because there are not yet minority shareholders, however, there will usually be no one able to sue for an injunction proscribing the original gift.

181. See SEC v. Harwyn Indus., 326 F. Supp. 943 (S.D.N.Y. 1971). See text accompanying notes 51-60 supra.

182. See note 179 supra and accompanying text. 
distribution of securities by an underwriter, ${ }^{183}$ the inquiry should not focus on the form of the spin-off. The donating corporation is the issuer, receiving value in the form of public ownership of its stock; the distributing corporation is an underwriter, participating in the distribution of a security ${ }^{184}$ but receiving no value from the spin-off itself. ${ }^{185}$ Because the recipient shareholders also participate in the undertaking, they should also be held liable under section 12 to the subsequent inarket purchasers. ${ }^{186}$ The SEC can attack these transactions as "acts or practices which constitute or will constitute a violation of the provisions of [the 1933 Act]." 187 The Commission can also brimg criminal charges against those in control of the issuer and of the distributing corporation. ${ }^{188}$

\section{Partnership Distributions}

A partnership, like a corporation, nnay serve as the intermediary in the distribution of stock between a private corporation and public investors. In such cases the critical inquiry is whether the partnership is a legal entity separate froin the recipient partners for the purposes of the 1933 Act. If the partnership is not a separate legal entity, a distribution of shares inerely preserves the existing pro rata ownership of partnership assets. Registration of the securities would not be necessary to a spin-off of stock purchased by the partnership. On the other hand, if the partnership is a distinct entity, the analysis of spin-offs applicable to corporations is likewise applicable to the partnership. Registration with the Securities and Exchange Commission would be necessary before a spin-off could be accoinplished legally.

Traditionally, a partnership is not a legal entity separate from the partners, but is rather an association of two or nore persons to carry on

183. The terms "distribution of a security" and "underwriter" are terms of art as defined in section 2(11) of the 1933 Act, 15 U.S.C. $\$ 77 \mathrm{~b}(11)$ (1976).

184. The transaction is an undertaking to offer or sell for an issuer in connection with a distribution of any security. 15 U.S.C. $\S 77 \mathrm{~b}(11)$ (1976). It is analogous to the more typical distribution through underwriters and a selling group.

185. It might seem that the corporation would not undertake the distribution without compensation. In fact, the compensation bypasses the corporation and flows directly to the shareholders. Compare SEC v. Datronics Eng'rs, Inc., 490 F.2d 250 (4th Cir. 1973), cert. denied, 416 U.S. 937 (1974), with SEC v. Harwyn Indus., 326 F. Supp. 943 (S.D.N.Y. 1971).

186. Even the innocent minority shareholders receive unjust enrichment at the expense of those who purchased from them in the market. However, the ininority shareholders should be able to cross-claim against the directors and majority shareholders of the distributimg corporation for damages due to breach of fiduciary duty. See F. O'Neal, Oppression of Minority SHareHOLDERS (1975).

187. Section 20,15 U.S.C. $\$ 77 t(b)$ (1976).

188. See United States v. Rubinson, 543 F.2d 951 (2d Cir. 1975), cert. denied, 429 U.S. 850 (1976). 
as co-owners of a business for profit. ${ }^{189}$ Arguably, any distribution of stock annong co-owners is just a bookkeeping entry to reflect true ownership of the shares. Therefore, no value and no sale are present when a partnership distributes stock. On the other hand, co-ownership of a business inerely signifies that the partners have ultimate control; 190 it must be distinguished from co-ownership of assets. ${ }^{191}$ In many legal circuinstances a partnership is considered an entity separate from the partners. ${ }^{192}$

The Uniform Partnership Act (UPA) ${ }^{193}$ provides that all property contributed to the partnership and all property acquired with partnership funds is property of the partnership. ${ }^{194}$ The property rights of a partner in partnership property are also defined by the UPA im sections 24-26. ${ }^{195}$ According to these provisions, all partners are co-owners of

189. See UNIForM PARTNership ACt § 6(1).

190. See id., Official Comment, Subdivision 1.

191. See, e.g., Provident Trust Co. v. Rankin, 333 Pa. 412, 5 A.2d 214 (1939).

192. See, e.g., Mazzuchelli v. Silberberg, 29 N.J. 15, 148 A.2d 8 (1959); Carle v. Carle Tool \& Eng'g Co., 36 N.J. Super. 36, 114 A.2d 738 (Super. Ct. App. Div. 1955); cf. Hartford Accident \& Indem. Co. v. Huddleston, 514 S.W.2d 676 (Ky. 1974) (entity theory will not be applied when it will produce unjust results).

193. Not all states have adopted the Uniform Partnership Act. As a result, a particular state's resolution of the aggregate-entity issue may result im different concepts of ownership of partnership assets. Federal law, however, controls the concepts of the Securities Act of 1933. The UPA provides an appropriate basis for the law of property ownership as it relates to the securities acts.

194. UNIFORM PARTNERSHIP ACT \& 8(2).

195. These sections provide:

$\S 24$. Extent of Property Rights of a Partner

The property rights of a partner are (1) his rights in specific partnership property, (2)

his interest in the partnership, and (3) his right to participate im the managenent.

$\S 25$. Nature of a Partner's Right in Specific Partnership Property

(1) A partner is co-owner with his partners of specific partnership property holding as a tenant in partnership.

(2) The mcidents of this tenancy are such that:

(a) A partner, subject to the provisions of this act and to any agreennent between the partners, has an equal right with his partners to possess specific partnership property for any other purpose without the consent of his partners.

(b) A partner's right im specific partnership property is not assignable except in connection with the assignment of rights of all the partners in the same property.

(c) A partner's right in specific partnership property is not subject to attachment or execution, except on a claim against the partnership. When partnership property is attached for a partnership debt the partners, or any of them, or the representatives of a deceased partner, cannot claim any right under the homestead or exemption laws.

(d) On the death of a partner his right in specific partnership property vests im the surviving partner or partners, except where the deceased was the last surviving partner, when his right in such property vests in his legal representative. Such surviving partner or partners, or the legal representative of the last surviving partner, has no right to possess the partnership property for any but a partnership purpose.

(e) A partner's right in specific partnership property is not subject 10 dower, curtesy, or allowances to widows, heirs, or next of kin.

$\S 26$. Nature of Partner's Interest in the Partnership

A partner's interest im the partnership is his share of the profits and surplus, and the same is personal property.

Id. $\S \S 24-26$. 
specific partnership property, holding as tenants in partnership. ${ }^{196}$ The partner's only right in the property as a tenant in partnership is the right to control the property for partnership purposes; ${ }^{197}$ the rights of the partner are not personal to him, nor do they survive him. ${ }^{198}$ Moreover, the only real indicium of ownership is the partner's share of partnership profits and surplus, which is personal property. ${ }^{199}$

In short, the provisions of the UPA indicate that a partner does not co-own specific partnership property in the same way that a person may co-own common stock as a tenant in common or in joint tenancy. ${ }^{200}$ The UPA, without debating the merits of the entity theory versus the aggregate theory, ${ }^{201}$ treats partnership property as if the partnership is a separate entity. ${ }^{202}$ For example, if a partnership has one hundred partners and the partnership owns ten thousand shares of common stock in a corporation, an imdividual partner has no right to possess his percentage of the investinent, and no right to sell his hundred shares. In addition, the partner's interest in the shares will not survive him.

Any distribution of stock from the partnership will change the partners' form of ownership, as would a corporate spin-off. ${ }^{203}$ After the distribution, the partner still inaintains his property rights in the remaining partnership assets and his interest in future profits and surplus. The partner also owns securities in a separate corporation. Simultaneously, the partnership distribution will decrease the value of the remaining partnership interest. ${ }^{204}$ As with a corporate spin-off, the partnership distribution of stock is a disposition for value, i.e., a sale. This interpretation is consistent with the inclusion of partnership $m$ the

196. Id. $\S \S 24,25(1)$.

197. Id. $\S 25(2)(\mathrm{a})-(\mathrm{c})$.

198. See id. $\S \S 25(2)(d), 25(2)(\mathrm{e})$.

199. Id. \$ 26.

200. See Salomon Bros. \& Hutzler v. Pedrick, 105 F. Supp. 210 (S.D.N.Y. 1952); State v. Elsbury, 63 Nev. 463, 175 P.2d 430 (1946); J. Crane, The Law of Partnerships $\$ 40$ (1952).

201. See generally 1 J. Barrett \& E. Seago, Partners and Partnerships: Law and TAXATION, ch. $3, \S 1.2$ (1956). The entity theory would treat a partnership as a legal entity separate from the shareholders, like a corporation. The aggregate theory, however, would treat a partnership as an aggregation of individuals.

202. See notes 195-201 supra, $\mathscr{c}$. UNIFORM PARTNERSHIP ACT $\$ 40$ (right to partnership property in settling of accounts after dissolution).

203. The distribution will be from profits and surplus from the partnership business and if that account is madequate to cover the distribution, then from the individual capital account of the partner. Some partnerships do not distinguish capital accounts from profits and surplus accounts.

204. The stock distribution will decrease the capital contribution of the partner, decrease the partnership property in which the partner has an interest, decrease the potential share of profits, and increase the investinent risk. See text accompanying notes 163-65 supra. 
1933 Act's definition of "person." 205 Therefore, a partner, like a shareholder, gives value in exchange for receipt of stock in a partnership distribution. The value takes the form of a reduction in the worth of the partner's only personal property interest-his interest in future profits and surplus of the partnership. Because there is value, there is also a sale, and registration should be required.

\section{Conclusion}

From 1936 to 1969 , securities lawyers were led to believe that spinoffs, like stock dividends, were not given for value and thus were not subject to registration under section 5 of the 1933 Act. Because the few courts deciding cases involving spin-offs have found violations of numerous securities laws, they liave not formulated a definition of value. The Securities and Exchange Commission has taken the view that a spin-off without prior registration is not a violation of the 1933 Act if both the distributing corporation and the issuing corporation are reporting compamies. The potential for abuse, however, requires the courts and the SEC to develop a inore exacting standard. The suggested approach is to hold that shareholders do give value in a spin-off, in the form of a decrease in the worth of the distributing corporation. The same value can be found in a partnership distribution of unregistered securities. Once one recognizes that spin-offs do require registration, the amount of information to be disclosed can be determined. The recipient sliareholders must receive, at a minimuin, enough information to resolve for theinselves whether the spun off stock is appropriate for their particular investinent strategy.

William L. Thompson, Jr.

205. Section 2(2), I5 U.S.C. $\$ 77 \mathrm{~b}(2)$ (1976). A "person" may not make a sale of unregistered stock (section 5, 15 U.S.C. $§ 77 \mathrm{e}(1976)$ ) and is liable under section 12, 15 U.S.C. $§ 77$, for doing so. 